\title{
FUNCTIONING OF NITRIC OXIDE CYCLE IN GASTRIC MUCOSA OF RATS UNDER EXCESSIVE COMBINED INTAKE OF SODIUM NITRATE AND FLUORIDE
}

\author{
O. Ye. AKIMOV, V. O. KOSTENKO \\ Ukrainian Medical Stomatological Academy, Poltava, Ukraine; \\ e-mail: riseofrevan@mail.ru
}

In the article the function of nitric oxide ('NO) cycle in rat's gastric mucosa was assessed under excessive combined chronic fluoride and nitrate intake during 30 days. It was estimated that general nitric oxide synthase activity (NOS) was increased during excessive sodium fluoride intake meanwhile influence on general nitrate reduction was not statistically significant, but general nitrite reduction was increased. General arginase activity decreased. Excessive sodium nitrate intake decreased NOS activity, but increased nitrate, nitrite reduction and general arginase activity. Combined sodium nitrate and fluoride intake increased NOS by $18.9 \%$, nitrate reduction by $71.7 \%$, nitrite by $161.5 \%$, arginase activity increase by $61.4 \%$. The highest amounts of peroxynitrite were obtained from excessive sodium fluoride intake group, excessive sodium nitrate intake showed the lowest levels and combined excessive sodium nitrate and fluoride intake levels had intermediate results. Summarizing the data obtained, the authors have made a conclusion that combined excessive sodium nitrate and fluoride intake creates optimal conditions for functioning of nitrate-nitrite reductases.

Ke y word s: nitric oxide, nitrate reductases, nitrite reductases, peroxynitrite, arginases.

$\mathrm{N}$ itric oxide $(\cdot \mathrm{NO})$ is known to be one of cell mediators and is involved in performing various functions. Some of its biological properties provide protective function (e.g. vasodilatation during heart ischemia), others may affect cell (e.g. peroxynitrite -mediated lipid peroxidation) [1]. In mammalians - $\mathrm{NO}$ is produced during enzymecontrolled reaction from L-arginine (L-ARG), however as it was shown in recent decade that is not the only way. The other one is earlier, and it involves the reduction of nitrate $\left(\mathrm{NO}_{3}^{-}\right)$to nitrite $\left(\mathrm{NO}_{2}^{-}\right)$and further reduction to nitric oxide ( $\mathrm{NO}$ ) [2]. The reduction pathway is the primary way of getting 'NO by bacteria and plants. Some structures of mammalian organisms were identified as possible agents capable of reducing $\mathrm{NO}_{2}$ to $\mathrm{NO}$ (myoglobin, hemoglobin, cytochrome) under specific conditions, which include hypoxia and acidosis. The nature of mammalian nitrate reductases still remains unknown [2]. However, it has been shown that dietary nitrates increase the levels of nitrite in the blood thus indicating the presence of some types of reductases [3]. Furthermore, the NO-synthetic pathway of L-ARG metabolism also is not the only the way. The alternative pathway includes activation of arginases (EC 3.5.3.1.). This pathway competes with NO-syntases (EC 1.14.13.39) for L-ARG. But it remains mostly inactive in physiological conditions. This situation changes drastically during pathogenic states [4]. It should be mentioned that the products formed from arginase-controlled LARG hydrolysis are L-ornithine and urea, L-ornithine is needed for synthesis of putrescine. It has been reported that arginase activation takes place during hypoxia and is associated with acidosis, but maximum activity is shown by agrinase under much more higher $\mathrm{pH}$ levels ( $\mathrm{pH}=9-10)$. Taking into consideration that urea is one of the arginase reaction products one may suggest the $\mathrm{pH}$ is slowly increasing during arginase overexpression. As it was mentioned above, peroxynitrite $\left(\mathrm{ONOO}^{-}\right)$is a dangerous metabolite of NO. It is formed during the reaction of $\cdot \mathrm{NO}$ with superoxide anion-radical $\left({ }^{\circ} \mathrm{O}_{2}{ }^{-}\right)$. This metabolite is responsible for increasing oxidative stress damaging cells as well as being one of the factors that can initiate the programmed cell death $[5,6]$. The organs of gastrointestinal tract are the first which respond to this intoxication. Salivary glands can reduce nitrate to nitrite and then to nitric oxide lessening the damage, which might be cased by some medicines [7]. Fluoride can damage the stomach mucosa and reduce its motor activity [8]. Fluoride can also activate inducible forms of NOS (iNOS). 
There are regions in Ukraine where concentration of fluorides exceeds hygienic norms. Poltava region can serve as a bright example of such regions. Inorganic and organic nitrates are used as fertilizers in agriculture. Thus the combined exposure to these two compounds through digestive system is possible. Nevertheless, there are little data on combined effects produced by these toxins on NO-cycle and on stomach mucosa.

The aim of this research was to find out influence of combined excessive sodium nitrate and fluoride intake on the functioning of NO-cycle in rat's stomach mucosa, by measuring activity of two of its core components: general NOS activity and nitratenitrite reduction activity.

\section{Materials and Methods}

The experiment involved 52 mature female and male rats with mean body weight 180-220 g. All animal experiments were performed in accordance with the rules of the European Convention for the Protection of Vertebrate Animals used for Experimental and Other Scientific Purposes (Strasbourg, 1986). Excessive fluoride intake was modeled by administration of water solution of sodium fluoride intragastrically in a dose of $10 \mathrm{mg} / \mathrm{kg}$ via special probe once a day before feeding for 30 days [9]. Nitrates were administered as water solution of sodium nitrate in the same mode in a dose of $500 \mathrm{mg} / \mathrm{kg}$ of body weight [10]. Combined intoxication was modeled by combining $10 \mathrm{mg} / \mathrm{kg}$ of sodium fluoride and $500 \mathrm{mg} /$ $\mathrm{kg}$ of sodium nitrate in one dose. The dosage was chosen depending on animals' body weight. Maximal volume of infusion was no more than $1 \mathrm{ml}$ per day to avoid stomach overstretching. The animals were euthanized in 30 days by thiopental overdosage $(45 \mathrm{mg} / \mathrm{kg}$ ). The internal organs were taken for biochemical analysis.

The stomach mucosa was removed from other layers with the scalpel and was rinsed with $0.9 \%$ sodium chloride solution. Then it was homogenized with $0.1 \mathrm{M}$ Tris-buffer ( $\mathrm{pH}$ 7.4) in cold to obtain $10 \%$ tissue homogenate.

Total activity of NO-synthases (NOS) was evaluated by increase in $\mathrm{NO}_{2}{ }^{-}$concentration after incubation of homogenated tissue samples for 30 min in the incubation solution $(2.5 \mathrm{ml} 0.1 \mathrm{M}$ Trisbuffer, $0.3 \mathrm{ml} 320 \mathrm{mM}$ L-ARG water solution and $0.1 \mathrm{ml} 1 \mathrm{mM}$ NADPH solution). The $10 \%$ homogenate $(0.2 \mathrm{ml})$ was taken for the analysis. Immediately after mixing homogenate with the incubation solu- tion, we took $0.2 \mathrm{ml}$ of it to evaluate the initial nitrite concentration. $1 \%$ sulfanilic acid in $30 \%$ acetic acid and 0.1\% 1-naphtylamine in the same solvent were chosen as nitrite specific reactants. Then we added $1.8 \mathrm{ml}$ of distilled water to $0.2 \mathrm{ml}$ of solution taken for initial nitrite assessment. Following this we added $0.2 \mathrm{ml}$ of $1 \%$ sulfanilamide acid and $10 \mathrm{~min}$ later $0.2 \mathrm{ml}$ of $0.1 \%$ 1-naphtylamine were added as well. The amount of nitrites was measured by spectrophotometer Ulab-101 (540 nm in cuvette with optical path length of $5 \mathrm{~mm}$ ). Concentration was calculated as $\mathrm{C}=0.30104 \cdot$ Absorbtion $(\mu \mathrm{mol} / \mathrm{g})[11,12]$.

Following incubation (30 $\mathrm{min})$ the reaction was stopped by adding $0.02 \mathrm{ml}$ of $0.02 \%$ sodium azide. Then $0.2 \mathrm{ml}$ was taken to assess final nitrite concentration. Total NOS activity was calculated as NOS $=\left(A_{2}-A_{1}\right) \cdot 2057 / N(\mu \mathrm{mol} / \mathrm{g} \cdot \mathrm{min})$, where $A_{2}$ means absorbance of solution taken for final nitrite measurement, $\mathrm{A}_{1}$ stands for absorbance of solution taken for initial nitrite measurement, $\mathrm{N}$ is the concentration of protein calculated by Biurette method g/l.

Total activity of arginases was assessed by using the following technique. First, $0.1 \mathrm{ml}$ of homogenate was taken to estimate initial level of L-ornithine. Then we used the modified Chinard's reactive [13]. The $0.2 \mathrm{M}$ phosphate buffer $(0.5 \mathrm{ml}, \mathrm{pH} 7.0)$ and $0.1 \mathrm{ml}$ of $2.5 \%$ ninhydrin on acidic mixture (2: $360 \%$ orthophosphoric and ice acetic acids and $6: 4$ with water) and $1.0 \mathrm{ml}$ of glacial acetic acid was added to $0.1 \mathrm{ml}$ of homogenate. The solution was boiled for $40 \mathrm{~min}$ to achieve maximal color yield. Then $1 \mathrm{ml}$ of $20 \%$ trichloracetic acid was added to precipitate proteins and after centrifugation (1000 g) for $30 \mathrm{~min}$ the absorbance of $1 \mathrm{ml}$ of supernatant was measured $\left(\mathrm{A}_{1}\right)(10 \mathrm{~mm}$ cuvette against water for $515 \mathrm{~nm}$ wavelength).

The activation of agrinase-dependent L-ARG metabolism can be designed under the following conditions: $20 \mathrm{~h}$ incubation in $0.5 \mathrm{ml}$ of $0.2 \mathrm{M}$ phosphate buffer ( $\mathrm{pH} 7.0$ ) and adding $0.2 \mathrm{ml}$ of $24 \mathrm{mM}$ solution of L-ARG at $37^{\circ} \mathrm{C}$. Then we carried out the procedure of L-ornithine assessment as described above $\left(A_{2}\right)$. Arginase activity was calculated by formula:

$$
\mathrm{V}=\left(232 \cdot \mathrm{A}_{2}-216 \cdot \mathrm{A}_{1}\right) /(1.2 \cdot \mathrm{N}) \mu \mathrm{mol} / \mathrm{g} \cdot \mathrm{min} \text {. }
$$

To assess the nitrate-nitrite reductase activity the concentration of nitrite and the same reagent used for assessing NOS activity was chosen. However, to measure the nitrate concentration, a resto- 
ration agent is needed. For this purpose we have chosen $0.55 \%$ water solution of hydrasin sulfate. NADH in a dose of $1 \mathrm{mg} / \mathrm{ml}$ solution was used as electron donor for nitrate-nitrite reductases as well. The method required 4 aliquots $0.1 \mathrm{ml}$ each. First, to avoid the absence of either nitrate anions or nitrite anions in homogenate, $1 \mathrm{ml}$ of $10 \mathrm{mM}$ sodium nitrate and $1 \mathrm{ml}$ of $10 \mathrm{mM}$ sodium nitrite were to be added to $0.1 \mathrm{ml} 10 \%$ tissue homogenate. To precipitate proteins $0.1 \mathrm{ml}$ of $6 \%$ zinc sulfate solution was used. Then we had to evaluate the nitrite concentration in the solution by adding $0.1 \mathrm{ml}$ of $1 \%$ sulfanilamide acid and $1 \mathrm{ml}$ of distilled water, and $10 \mathrm{~min}$ later we added $0.1 \mathrm{ml}$ of $0.1 \%$ 1-naphtylamine with $1 \mathrm{ml}$ of distilled water. Then 10-min centrifugation (1000 g) followed. The next step was to determine the absorbtion of $1 \mathrm{ml}$ supernatant in $10 \mathrm{~mm}$ cuvette against water for $540 \mathrm{~nm}$ wavelength $\left(\mathrm{A}_{1}\right)$. To estimate total nitrate and nitrite concentration prior incubation we added $0.1 \mathrm{ml}$ of $6 \%$ zinc sulfate solution, then $0.1 \mathrm{ml}$ $0.55 \%$ hydrasine sulfate solution was added and incubated for $10 \mathrm{~min}$ at $40{ }^{\circ} \mathrm{C}$. Then we carried out the procedure of nitrite concentration assessment as described above $\left(A_{2}\right)$.

The remaining two aliquots were incubated in $1 \mathrm{ml}$ of $0.2 \mathrm{M}$ phosphate buffer ( $\mathrm{pH} 7.0)$ in the presence of $0.1 \mathrm{ml} 1 \mathrm{mg} / \mathrm{ml} \mathrm{NADH}$ in sealed tubes. Aliquot $3\left(\mathrm{~A}_{3}\right)$ was subjected to the same procedure as described for aliquot 2, and aliquot $4\left(\mathrm{~A}_{4}\right)$ was subjected to the same procedure as described for aliquot 1 . $A_{1}$ represents the nitrite concentration prior the incubation, $\mathrm{A}_{2}$ represents the total nitrate concentration reduced by hydrosine, and nitrite concentration prior the incubation. $\mathrm{A}_{3}$ stands for remaining total amount of nitrates reduced by hydrosine and nitrites and $\mathrm{A}_{4}$ shows the remaining nitrites only. Thus, the activities of nitrate-reductases can be summarized by formula:

$$
\begin{aligned}
& \mathrm{R}_{1}=1000 \cdot\left(\left(137.5 \cdot \mathrm{A}_{2}-110 \cdot \mathrm{A}_{1}\right)-\right. \\
& \left.-\left(170 \cdot \mathrm{A}_{3}-142.5 \cdot \mathrm{A}_{4}\right)\right) /(60 \cdot \mathrm{N})
\end{aligned}
$$

and nitrite reductases:

$$
\begin{aligned}
& \mathrm{R}_{2}=1000 \cdot\left(137.5 \cdot \mathrm{A}_{2}-\left(142.5 \cdot \mathrm{A}_{4}-\right.\right. \\
& -(\mathrm{X}-\mathrm{Y}))) /(60 \cdot \mathrm{N}),
\end{aligned}
$$

where $X=\left(137.5 \cdot A_{2}-110 \cdot A_{1}\right), Y=\left(170 \cdot A_{3}-142.5 \cdot A_{4}\right)$. We should point out on that nitrite reductase activity formula takes account of nitrite anions produced by nitrate reductase. All the activities are presented as $\mu \mathrm{mol} / \mathrm{g} \cdot \mathrm{min}$.

Peroxynitrite concentration was measured by using its reaction with potassium iodide under
$\mathrm{pH} 7.0$ in $0.2 \mathrm{M}$ phosphate buffer with the same $\mathrm{pH}$ [14]. For this purpose we took $0.1 \mathrm{ml}$ of homogenate, which then was solved in $3.9 \mathrm{ml}$ of $0.2 \mathrm{M}$ phosphate buffer ( $\mathrm{pH} 7.0$ ). Then $1 \mathrm{ml}$ of $5 \%$ potassium iodide was added. Test tubes with the mixture were shaken vigorously for $2 \mathrm{~min}$. The following centrifugation (1000 g) lasted $10 \mathrm{~min}$. Then we assessed the absorbance of $1 \mathrm{ml}$ of upper layer against the control ( $1 \mathrm{ml}$ of solution containing $1 \mathrm{ml}$ of $5 \%$ potassium iodide and $4 \mathrm{ml}$ of $0.2 \mathrm{M}$ phosphate buffer, $\mathrm{pH}$ 7.0) in $10 \mathrm{~mm}$ cuvette at $355 \mathrm{~nm}$ wavelength. The peroxynitrite concentration was calculated by the formula: $\mathrm{C}=\mathrm{A} \cdot 20 ; \mu \mathrm{mol} / \mathrm{g}$ (here $\mathrm{g}$ means the organ mass in grams).

The data obtained were statistically processed by ANOVA and the following post-hoc GamesHowell test if the data had normal distribution. In case of different distribution, the data processing was carried out by Kruskal-Wallis and post-hoc Scheffe tests. The difference was statistically significant if $P<0.05$. Data were represented as mean \pm standard error of mean.

\section{Results and Discussion}

The analysis of findings obtained shows (Table) that excessive fluoride intake elevates the total NOS activity by $120.7 \%$. This can be explained by the activation of inducible NOS. Fluoride intoxication produces no effect on nitrate-reductase activity, but nitrite reductase activity has increased by $85.6 \%$ that can be explained by tissue hypoxia following fluoride intoxication [15]. Under such conditions ${ }^{*} \mathrm{NO}$ is oxidated by oxygen present in the tissues to nitrite $\left(\mathrm{NO}_{2}\right)$ providing substrate induction for nitritereductases. Being competitors for L-ARG with NOS, arginases lose their substrate and reduce their activity by $40 \%$.

Nitrate intoxication provides an increase in nitrate-reductases activity by $76.3 \%$, nitrite induction increases as well but by $85 \%$. Nitrate reduction can obviously provide more substrate for nitritereductases than they can reduce to nitric oxide for $1 \mathrm{~min}$ thus resulting in the increase of nitrite concentration in the tissues. This increased nitrite concentration may produce adverse effect upon the body due to high instability of newly formed nitrite. It can easily initiate nitrosilation reactions thus increasing the damage to tissue proteins. Activity of NOS is reduced by $35 \%$ as the most amount of nitric oxide is generated by reductive pathway that leaves more substrate to arginases, and their activity increases 
Metabolic changes in rat's gastric mucosa under excessive combined intake of sodium nitrate and fluoride $(M \pm m)$

\begin{tabular}{|c|c|c|c|c|}
\hline \multirow[b]{2}{*}{ Parameters } & \multicolumn{4}{|c|}{ Groups } \\
\hline & Control, $n=10$ & $\begin{array}{c}\text { Fluoride } \\
\text { intoxication, } \\
n=13\end{array}$ & $\begin{array}{c}\text { Nitrate } \\
\text { intoxication, } \\
n=14\end{array}$ & $\begin{array}{c}\text { Combined } \\
\text { intoxication, } \\
n=15\end{array}$ \\
\hline $\begin{array}{l}\text { Nitrate-reductase, nmol } \\
\left(\mathrm{NO}_{3}\right) / \text { min } \cdot \mathrm{mg} \text { of protein }\end{array}$ & $5.98 \pm 0.74$ & $6.09 \pm 1.05$ & $10.54 \pm 1.08^{*, * *}$ & $10.27 \pm 0.63^{*, * * ; \#}$ \\
\hline $\begin{array}{l}\text { Nitrite- reductase, nmol } \\
\left(\mathrm{NO}_{2}\right) / \mathrm{min} \cdot \mathrm{mg} \text { of protein }\end{array}$ & $4.32 \pm 0.69$ & $8.02 \pm 1.23^{*}$ & $7.99 \pm 1.45^{*}$ & $11.30 \pm 0.48^{*, * *, \#}$ \\
\hline $\begin{array}{l}\text { NO-syntases, nmol }\left(\mathrm{NO}_{2}\right) / \\
\text { min'mg of protein }\end{array}$ & $6.51 \pm 0.41$ & $14.37 \pm 0.82 *$ & $4.23 \pm 0.36^{*, * *}$ & $7.74 \pm 0.27^{* * * *, \#}$ \\
\hline $\begin{array}{l}\text { Arginases, nmol } \\
\text { (L-ornithine)/ } \\
\text { min·mg of protein }\end{array}$ & $2.07 \pm 0.08$ & $1.24 \pm 0.11^{*}$ & $3.77 \pm 0.38^{*, * *}$ & $3.34 \pm 0.08^{*, * *, \#}$ \\
\hline Nitrite, nmol/g & $11.59 \pm 0.51$ & $19.59 \pm 0.46^{*}$ & $9.25 \pm 0.44^{*, * *}$ & $18.9 \pm 0.8^{*, \#}$ \\
\hline Peroxynitrite, $\mu \mathrm{mol} / \mathrm{g}$ & $0.88 \pm 0.06$ & $2.47 \pm 0.09 *$ & $0.48 \pm 0.03^{*, * *}$ & $1.48 \pm 0.06^{*, * *, \#}$ \\
\hline
\end{tabular}

by $82.1 \%$. NOS activity is obviously reduced (by $71 \%$ ) compared to fluoride intoxication, this can be explained by inhibition of NOS by excessive ${ }^{\mathrm{N} O}$ formation in nitrate-nitrite reductive pathway. There is an increase in nitrate-reductase activity by $73 \%$, compared to fluoride intoxication, but there is no significant difference in nitrite-reductases activity. Arginases activity is increased by $204 \%$.

Combined intoxication has shown both nitrite and nitrate reduction systems increase, but the amount of the substrate they convert is nearly identical. This can indicate that combined action of fluoride and nitrate produces optimal conditions for nitrate-nitrite reduction process. Ironically, NOS activity also increases (by 18.9\%). As constitutional NOSs are regulated by ${ }^{\circ} \mathrm{NO}$ concentration, we can conclude this increase results from inducible form of NOS. The iNOS increases its activity considerably during inflammatory processes. As a stomach is one of the organs especially exposed to the action of these two toxic substances, we can suggest that fluoride induces damage to gastric mucosa by stimulating tissue macrophages. They in turn produce excessive amount of nitric oxide via iNOS activation. Arginase activity enhanced by $61.4 \%$ contributes to NO-cycle dysregulation. We should point out that the activity of arginases was measured in this study in conditions of substrate presence (24 mM L-ARG so- lution). The question is whether such conditions are present in mucosa remains unknown. Anyway, this situation will result in elevated L-ARG consumption.

To evaluate potential danger due to increased -NO production it is necessary to consider the peroxynitrite amount formed in the tissue. Fluoride intoxication increases peroxynitrite amount by $180.7 \%$, while nitrate intoxication reduces it by $45.5 \%$. Increased $\cdot \mathrm{NO}$ generation might be expected to lead to increased peroxynitrite concentration but there is evidence that nitric oxide can regulate the generation of reactive oxygen species in mitochondria (superoxide in particular) [16]. The combined intoxication by fluoride and nitrate shows that nitrates attenuate excessive peroxynitrite formation to some extent, when compared to fluoride intoxication group, but the concentration is still increased (by 68.2\%) compared to control group.

Thus, combined fluoride and nitrate intoxication provides good conditions for functioning of nitrate-nitrite reduction pathway, allowing this pathway to take charge in 'NO generation, leaving L-ARG for arginase pathway.

The issue whether excessive arginase activation leads to the formation of putrescine and spermidine, which in turn enhance stomach mucosa regeneration is little known and therefore seems to be promising. 


\section{ФУНКЦІОНУВАННЯ ЦИКЛУ ОКСИДУ АЗОТУ В СЛИЗОВІЙ ОБОЛОНЦІ ШЛУНКА ЩУРІВ ЗА НАДМІРНОГО КОМБІНОВАНОГО НАДХОДЖЕННЯ НІТРАТУ ТА ФТОРИДУ НАТРІЮ}

\section{О. С. Акімов, В. О. Костенко}

\section{ВДНЗУ «Українська медична стоматологічна академія», Полтава, Україна; e-mail: riseofrevan@mail.ru}

У статті розглядається функціонування циклу оксиду азоту ('NO) в умовах хронічного надмірного комбінованого надходження фторидів та нітратів протягом 30 днів. Встановлено, що загальна NO-синтазна активність (NOS) y групі надмірного надходження фториду натрію збільшувалась, у той самий час нітратредуктазна активність статистично значуще не змінювалась, але загальна нітрит-редуктазна активність збільшувалась. Загальна аргіназна активність знижувалась. Надмірне надходження нітрату натрію знижувало загальну NOсинтазну активність, підвищуючи при цьому нітрат-редуктазну, нітрит-редуктазну та загальну аргіназну активність. Надмірне поєднане надходження нітрату та фториду натрію збільшувало загальну NO-синтазну активність на $18,9 \%$, нітрат-редуктазну активність на $71,7 \%$, нітрит-редуктазну на $161,5 \%$ та загальну аргіназну активність на 61,4\%. Найбільшу кількість пероксинітриту було зафіксовано в групі надмірного надходження фториду натрію, найменшу - у разі надмірного надходження нітрату натрію. Поєднане надмірне надходження нітрату та фториду натрію показало проміжні результати. Дійшли висновку, що поєднане надмірне надходження нітрату та фториду натрію створює оптимальні умови для функціонування нітрат-нітрит редуктаз.

К л ю ч о в і с ло ва: оксид азоту, нітратредуктази, нітрит-редуктази, пероксинітрит, аргінази.

\section{ФУНКЦИОНИРОВАНИЕ ЦИКЛА ОКСИДА АЗОТА В СЛИЗИСТОЙ \\ ОБОЛОЧКЕ ЖЕЛУДКА \\ КРЫС ПРИ ИЗБЫТОЧНОМ \\ КОМБИНИРОВАННОМ \\ ПОСТУПЛЕНИИ НИТРАТА И ФТОРИДА НАТРИЯ}

О. Е. Акимов, В. А. Костенко

ВГУЗ Украины «Украинская медицинская стоматологическая академия», Полтава, Украина; e-mail: riseofrevan@mail.ru

В статье рассматривается функционирование цикла оксида азота ('NO) в условиях хронического избыточного комбинированного поступления фторидов и нитратов на протяжении 30 дней. Установлено, что общая NO-синтазная активность (NOS) в группе избыточного поступлення фторида натрия увеличивалась, в тоже время нитрат-редуктазная активность статистически значимо не изменялась, но общая нитритредуктазная активность увеличивалась. Общая аргиназная активность снижалась. Избыточное поступление нитрата натрия снижало общую NO-синтазную активность, повышая при этом нитрат-редуктазную, нитрит-редуктазную и общую аргиназную активность. Избыточное сочетанное поступление нитрата и фторида натрия увеличивало общую NO-синтазную активность на $18,9 \%$, нитрат-редуктазную активность на $71,7 \%$, нитрит-редуктазную на $161,5 \%$ и общую аргиназную активность на $61,4 \%$. Наибольшее количество пероксинитрита зафиксировано в группе избыточного поступления фторида натрия, наименьшее - при избыточном поступлении нитрата натрия. Сочетанное избыточное поступление нитрата и фторида натрия показало промежуточные результаты. Сделан вывод о том, что сочетанное избыточное поступление нитрата и фторида натрия создает оптимальные условия для функционирования нитрат-нитрит редуктаз.

К л ю че в ы е с ло в а: оксид азота, нитратредуктазы, нитрит-редуктазы, пероксинитрит, аргиназы. 


\section{References}

1. Morita M, Naito Y, Yoshikawa T, Niki E. Plasma lipid oxidation induced by peroxynitrite, hypochlorite, lipoxygenase and peroxyl radicals and its inhibition by antioxidants as assessed by diphenyl-1-pyrenylphosphine. Redox Biol. 2016; 8: 127-135.

2. Lundberg JO, Weitzberg E, Gladwin MT. The nitrate-nitrite-nitric oxide pathway in physiology and therapeutics. Nat Rev Drug Discov. 2008; 7(2): 156-167.

3. Jin L, Qin L, Xia D, Liu X, Fan Z, Zhang C, Gu L, He J, Ambudkar IS, Deng D, Wang S. Active secretion and protective effect of salivary nitrate against stress in human volunteers and rats. Free Radic Biol Med. 2013; 57: 61-67.

4. Durante W, Johnson FK, Johnson RA. Arginase: a critical regulator of nitric oxide synthesis and vascular function. Clin Exp Pharmacol Physiol. 2007; 34(9): 906-911.

5. Szabó C, Ischiropoulos H, Radi R. Peroxynitrite: biochemistry, pathophysiology and development of therapeutics. Nat Rev Drug Discov. 2007; 6(8): 662-680.

6. Kaydashev IP, Nozhinova OA, Bobrova NA, Riabenko VV, Bondarenko VV, Kostenko VA, Gargovich AL. Apoptosis in the cells of parenchymatous organs in subacute sodium nitrate poisoning. Tsitol Genet. 2000; 34(3): 6268. (In Russian).

7. Jin L, Qin L, Xia D, Liu X, Fan Z, Zhang C, Gu L, He J, Ambudkar IS, Deng D, Wang S. Active secretion and protective effect of salivary nitrate against stress in human volunteers and rats. Free Radic Biol Med. 2013; 57: 61-67.

8. Amira S, Mulè F. Effects of sodium fluoride on the mechanical activity in mouse gastric preparations. Can J Physiol Pharmacol. 2005; 83(4): 367-373.

9. Stasiuk OA, Kostenko VO. Effect of peroxynitrite scavangers on oxidative processes in salivary gland tissues of white rats under sodium nitrate and fluoride combined excessive intake. Probl Ecol Med. 2012; 16(5-6): 30-33. (In Ukrainian).

10. Kmet TI Vlasik LI. Nitrate-Cadmium intoxication in animals and protective effect tincture of Echinacea purpurea. Probl Nutrition. 2004; 3: 41-45. (In Ukrainian).

11. Green LC, Wagner DA, Glogowski J, Skipper PL, Wishnok JS, Tannenbaum SR. Analysis of nitrate, nitrite, and [15N]nitrate in biological fluids. Anal Biochem. 1982; 126(1): 131-138.

12. Koreshkov AP. Fundamentals of Analytical Chemistry. M.: Publishing house "Chemistry". 1970. Vol. 1. 472 p.

13. Khramov VA, Listopad GG. Modification in the determination of ornithine by Chinard's method and its use for quantitative determination of serum arginase. Lab Delo. 1973;10:591-2. Russian.

14. Shraibman GN, Dyagileva EP, Skibina AV. Spectrophotometric methods of determination of the peroxynitrite and the nitrite. Bull Kemerovo State University. 2011; 45: 200-206. (In Russian).

15. Sireli M, Bulbul A. The effect of acute fluoride poisoning on nitric oxide and methemoglobin formation in guinea pig. Turk $J$ Vet Anim Sci. 2004; 28: 591-595.

16. Wang Y, Loake GJ, Chu C. Cross-talk of nitric oxide and reactive oxygen species in plant programed cell death. Front Plant Sci. 2013; 4: 314.

Received 15.09.2016 